\title{
多变量解析による前立腺癌予後因子の検討
}

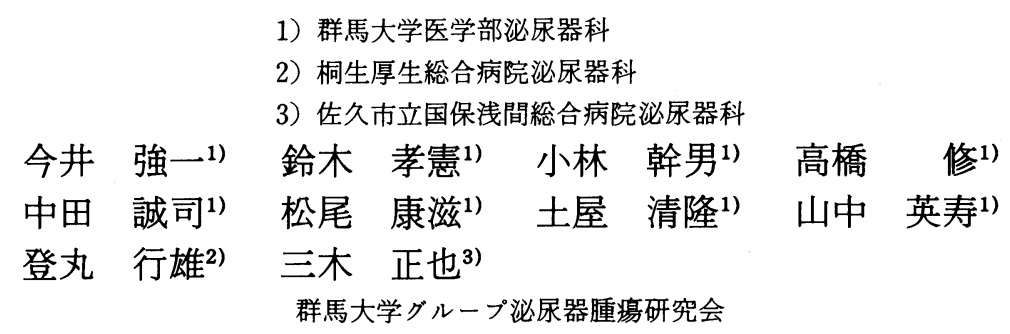

\section{THE ANALYSIS OF PROGNOSTIC FACTORS FOR PROSTATE CANCER BY MULTIVARIATE ANALYSIS}

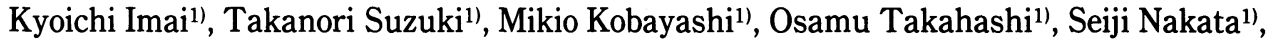 \\ Yasushige Matsuo ${ }^{1)}$, Kiyotaka Tsuchiya ${ }^{1)}$, Hidetoshi Yamanaka ${ }^{1)}$, \\ Yukio Tomaru' ${ }^{2)}$ and Masaya Miki ${ }^{3)}$ \\ 1) Department of Urology, Gunma University School of Medicine \\ 2) Department of Urology, Kiryu Kosei Hospital \\ 3) Department of Urology, Asama General Hospital
}

Multivariable analysis (quatification method I and II) was used to investigate the relationship between survival rates and prognostic factos. The items studied were age, stage, pathological differentiation, gait disturbance, acid phosphatase and erythrocyte sedimentation rate (ESR). The data were available for 353 patients for all items.

The significance of each item was evaluated in all patients-group, subgroup stratified by their cause of death, and subgroup stratified by their stage. The significance of age and gait disturbance which represent the general condition was proven in all patients, non-cancer death group and stage $\mathrm{ABC}$ group. In the cancer death group, stage $\mathrm{D}$ group was the most significant as prognostic factor. ESR was the most significant in the stage $D$ group and the significance was gradually increased with the observation time.

Key words: prostate cancer, prognostic factor, multivariate analysis

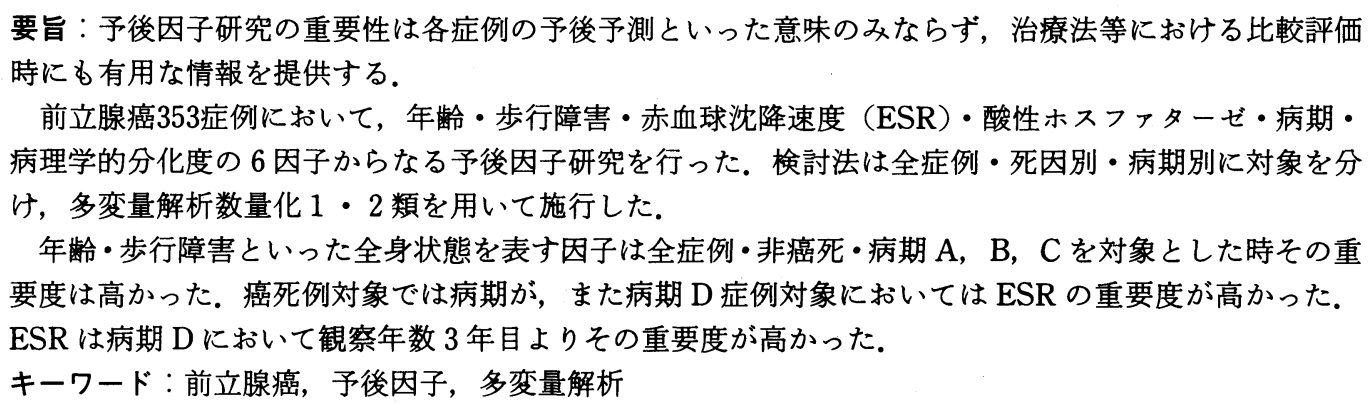

\begin{abstract}
緒言
前立腺癌予後因子の研究を, 年齢・病期・病理学的 悪性度・腫瘍マーカー・活動性・赤血球沈降速度 (ESR)
\end{abstract} の 6 項目を対象に, 生存因子と（前立腺）癌死因子と
いら視点より行った。これらの中で前 4 因子は腫瘍学 に拈ける予後因子として基本的なものであり ${ }^{1) ~ 5) ， そ ~}$ れぞれ生存因子ないしは癌死因子として有効な予後因 子であることが前立腺癌に拈いても唱えられてい 
る ${ }^{1224)}$ ．高齢者に見られる本疾患の予後は合併症ある いは活動性といった患者の健康度とも関係があり，症 例の全身状態を表す因子を含んだ研究方法が採用され る事が望ましい。この全身状態を表す因子として medical score $\mathrm{s}^{6}$. performance status ${ }^{7}$ 等が使用されてい る。しかし，これらは生存予後にて評価した時は有効 な因子となり得ても, 癌死予後との関連性では疑問が 持たれる因子である.

そこで，上記因子中より腫瘍学上の基本因子・症例 数・単独因子としての生存予後に対する有用性等を考 慮して年齢・病期・病理学的分化度・腫瘍マーカー・ 活動性としての歩行障害の程度・ESR を選び，それら の予後因子としての重要性を前立腺癌症例全体・病期 $\mathrm{D}$ の症例あるいは癌死症例の 3 種に層別化し, 多変量 解析にて再評価した。

\section{対象と方法}

1974 1988年に群馬大学ならびにその関連病院で発 見された新鮮前立腺癌1,087症例中, 検討項目 (Table 1）がすべて記載されていた353例を対象とした。年齢 因子は50歳以下・60歳代・70歳代・80歳以上の 4 群に 分類された。病期ならびに病理学的悪性度分類（以後 分化度) は前立腺癌取扱い規約8) ${ }^{8}$ 従った. ESR は 1 時 間値をもって検討し， $20 \mathrm{~mm}$ 以下・21 $49 \mathrm{~mm} \cdot 50 \mathrm{~mm}$ 以上の 3 群に分類した. ESR は外的要因によって容易 に影響を受けるので，入院と同時に検査された場合の みを評価対象とした。歩行障害は独歩入院・車椅子入 院・担送入院に分類された。酸性ホスファターゼ(AP) は治療前値を対象とし, 正常・異常の 2 群にて検討を した. AP 值は RIA 法にて41例, 総 AP 法にて82例, 前立腺性 AP 酵素法にて230例が測定されていた。

各因子 (以後 item)の category 方向，すなわち年齢 なら高齢化に・歩行障害は無より有りに・ESR は低値 より高値へ・病期は進行に・分化度は未分化に・AP は 異常值に向かい予後不良と予想した，検討結果がこの 予想に沿った時は正の相関とし, 逆の時は負の相関と した。

今回は治療因子は割愛したが，95\%以上の症例にお いて去勢術・エストロゲン・プロゲステロン・LHRH アナローグあるいはエストラサイト療法等の内分泌療 法が施行されていた。

本研究でも item 別に癌死因子としての有用性を評 価した。死因は, 各医療機関毎に死亡台帳・電話ある いは手紙により調査されその報告に従い決定された。

生存率は generalized Wilcoxon 法により, 他は $\chi^{2}$ 検定により評価され， $\mathrm{p} \leqq 0.05$ にて有意の差あるいは 相関が有ると判断した。 また多変量解析は数量化 1 類
Table 1 Items studied for all patients

\begin{tabular}{|c|c|c|c|c|}
\hline \multirow{2}{*}{ item } & \multicolumn{4}{|c|}{ category } \\
\hline & 1 & 2 & 3 & 4 \\
\hline age & $\begin{array}{l}\leqq 59 \\
(19)\end{array}$ & $\begin{array}{r}60-69 \\
(85)\end{array}$ & $\begin{array}{l}70-79 \\
(180)\end{array}$ & $\begin{array}{l}\geqq 80 \\
(69)\end{array}$ \\
\hline $\begin{array}{l}\text { gait } \\
\text { disturbance }\end{array}$ & $\begin{array}{l}\text { can walk } \\
(282)\end{array}$ & $\begin{array}{l}\text { on chair } \\
(51)\end{array}$ & $\begin{array}{c}\text { inIbed } \\
(20)\end{array}$ & \\
\hline ESR & $\begin{array}{r}\leqq 20 \\
(172)\end{array}$ & $\begin{array}{r}21-50 \\
(120) \\
\end{array}$ & $\begin{array}{l}<50 \\
(61) \\
\end{array}$ & \\
\hline $\mathrm{AP}$ & $\begin{array}{c}\text { normal } \\
(151)\end{array}$ & $\begin{array}{c}\text { abnormal } \\
(202)\end{array}$ & & \\
\hline stage & $\begin{array}{l}\mathrm{A} \\
(27)\end{array}$ & $\underset{(61)}{B}$ & $\begin{array}{l}\mathrm{C} \\
(73)\end{array}$ & $\underset{(192)}{\mathrm{D}}$ \\
\hline $\begin{array}{l}\text { tumor } \\
\text { differentiation }\end{array}$ & $\begin{array}{l}\text { well } \\
(56)\end{array}$ & $\underset{(153)}{\operatorname{moderately}}$ & $\begin{array}{l}\text { poorly } \\
\text { (144) }\end{array}$ & \\
\hline
\end{tabular}

( ) : number of patients

Table 2 Independency of items studied

\begin{tabular}{l|c|c|c|c|c}
\hline & AP & $\begin{array}{l}\text { tumor } \\
\text { differentiation }\end{array}$ & stage & ESR & $\begin{array}{l}\text { gait } \\
\text { disturbance }\end{array}$ \\
\hline age & $* *$ & ns & ns & ns & $* * *$ \\
\hline $\begin{array}{l}\text { gait } \\
\text { disturbance }\end{array}$ & ns & ns & ns & $* *$ & \\
\hline ESR & ns & ns & ns & & \\
\hline stage & $* *$ & $* *$ & & & \\
\hline $\begin{array}{l}\text { tumor } \\
\text { differentiation }\end{array}$ & $* * *$ & & & & \\
\hline
\end{tabular}

ns : not significant, ${ }^{* *}: \mathrm{p} \leqq 0.01,{ }^{* * *}: \mathrm{p} \leqq 0.001$

と 2 類で行った ${ }^{9)}$.

\section{結 果}

I. 各 item の基本的検討

前立腺癌予後因子研究において ESRを itemとし て使用した多変量解析報告はない。ここでは ESRを 中心に各 item の独立性と重要度の確認を行った。

検討 item 間の重複を避ける目的と，相関性が強い item 間に打ける互いの干渉により生ずる多变量解析 の正確な評価の妨げを防止するために，解析を行う前 に各 item 間の独立性を $\chi^{2}$ 検定にて検討した，年龄と 歩行障害・年齢と AP - 歩行障害と ESR - 病期と分化 度・病期と AP・分化度と AP に有意の正の相関を示し た（Table 2). 死因別（III項参照）あるいは病期別 （IVの項参照）にも各 itemの独立性を検討したが，全 症例に打ける場合とほぼ同様の結果であったので割愛 した。病期・分化度・年跉・腫瘍マーカー（AP）といっ た item は相互に相関性を示す事が多かったが，これ ら緒言でも述べた様に予後因子研究（特に前立腺癌に おいて）の基本的骨格を成するのと考えられたので対 象 item として使用した. ESR と歩行障害に相関性が 
認められたが，（1）歩行障害と年齢に相関（ $\mathrm{p} \leqq 0.01 ）$ が認められたものの ESR と年跉間には認められな かった.（2）ESRの年齢は以後に提示された結果の如 く item として異なった動きをしている部分があった 事の 2 点より異なった性格を有する item として使用 を決定した。

各 item 別に，それぞれの category 間で生存曲線の 統計的検定を施行した (Table 3). 歩行障害・ESR・ 分化度にすべての category 間で有意の差を認めた。 また, 年齢では70歳代と 80 歳以上, 病期では $\mathrm{B}$ と D な らびに C と D の category 間にのみ有意の差が認めら れた。 APでは有意の差は認められなかった。

II. 全症例に打梳多輁解析

診断から死亡日までの生存日数を数量化 I 類より得 られた偏相関係数により検討した。偏相関係数は他因 子の影響を除いた各因子の予後に対する重みと考える ことができる。この重みに従い生存予後不良の順位決 定すると, $\mathrm{ESR} \cdot$ 病期・歩行障害・分化度・年齢・AP であった，全身状態を表す item が比較的上位を占め ていた。 各 item の categoryを検討すると歩行障害・ $\mathrm{ESR}$ ・分化度は正の相関性を示したが，年齢（50歳 代)・病期（特に A ) ・AP（正常）に抢いては負の相関 性を示した (Table 4).この問題は考察のところで再 び述べる事とする。この時の基準日数は1,167.5日, 重 相関係数は0.4181であった。

数量化II 類にて年度別に生存予後に対する関連性を 検討した (Table 5)。年齢の偏相関係数は経過と共に 上昇し, 逆に分化度は下降の傾向がみられた。また $\mathrm{AP}$ は常に低い值を示した. item 全体の中で個々の重をみ 決定するといった意味からすると各年度における順位 はめまぐるしく変り，有効な情報とはならなかった。 この原因を前立腺癌死が全死因中に約 $50 \%$ の みしか含 まれないことにあると考え, 死因別に解析を行った。

\section{III. 死因別多变量解析}

前立腺癌死と他因死に分け，各 item との相関をみ た. 全死亡例183例の内訳は, 前立腺癌死83例・他因死 80 例・不明 20 例であった。不明を除いた163例にて死因 との相関性検討を行った．年齢・病期・AP に有意の差 が認められ，ESR・分化度・歩行障害には有意の相関

Table 3 Statistical evaluation for survival rates

\begin{tabular}{|c|c|c|c|c|c|c|}
\hline \multirow{2}{*}{ item } & \multicolumn{6}{|c|}{ category } \\
\hline & 1 vs 2 & 1 vs 3 & 1 vs 4 & 2 vs 3 & 2 vs 4 & 3 vs 4 \\
\hline age & ns & ns & ns & ns & ns & ** \\
\hline $\begin{array}{l}\text { gait } \\
\text { disturbance }\end{array}$ & $* *$ & $* *$ & - & $* *$ & - & - \\
\hline ESR & $* *$ & $* *$ & - & $* *$ & - & - \\
\hline $\mathrm{AP}$ & ns & - & - & - & - & - \\
\hline stage & ns & ns & ns & ns & $* *$ & ** \\
\hline $\begin{array}{l}\text { tumor } \\
\text { differentiation }\end{array}$ & * & $* *$ & - & $* *$ & - & - \\
\hline
\end{tabular}

ns : not significant, ${ }^{*}: \mathrm{p} \leqq 0.05, \quad{ }^{* *}: \mathrm{p} \leqq 0.01$,

$(-)$ : no evaluable category

Table 4 Multivariate analysis by quantification method I (in all patients)

\begin{tabular}{|c|c|c|c|c|c|}
\hline \multirow{2}{*}{ item } & \multicolumn{4}{|c|}{ category } & \multirow{2}{*}{$\begin{array}{c}\text { partial } \\
\text { coefficient }\end{array}$} \\
\hline & 1 & 2 & 3 & 4 & \\
\hline age & -59.2 & 95.6 & 33.5 & -180.8 & $0.1300(5)$ \\
\hline $\begin{array}{l}\text { gait } \\
\text { disturbance }\end{array}$ & 82.2 & -306.3 & -56.6 & & $0.1966(3)$ \\
\hline ESR & 135.5 & -8.7 & -305.4 & & $0.2122(1)$ \\
\hline AP & -37.0 & 20.9 & & & $0.0378(6)$ \\
\hline stage & -276.9 & 14. 4 & 293.0 & -69.4 & $0.2098(2)$ \\
\hline $\begin{array}{l}\text { tumor } \\
\text { differentiation }\end{array}$ & 326.5 & 25.7 & -89.6 & & $0.1683(4)$ \\
\hline
\end{tabular}

Table 5 Multivariate analysis by quantification method II (in all patients)

\begin{tabular}{l|c|c|c|c|c|c}
\hline $\begin{array}{l}\text { No. of alive PTS } \\
\text { No. of dead PTS }\end{array}$ & $\begin{array}{r}283 \\
47\end{array}$ & $\begin{array}{r}213 \\
86\end{array}$ & $\begin{array}{c}143 \\
127\end{array}$ & $\begin{array}{r}92 \\
150\end{array}$ & $\begin{array}{r}66 \\
160\end{array}$ & $\begin{array}{c}39 \\
171\end{array}$ \\
\hline observation year & 1 & 2 & 3 & 4 & 5 & 6 \\
\hline age & $0.1269(3)$ & $0.0862(5)$ & $0.0898(5)$ & $0.1277(4)$ & $0.1450(3)$ & $0.2534(1)$ \\
gait disturbance & $0.2690(1)$ & $0.1821(3)$ & $0.2435(1)$ & $0.1603(3)$ & $0.1039(5)$ & $0.1550(3)$ \\
ESR & $0.0591(5)$ & $0.0926(4)$ & $0.2088(2)$ & $0.2125(1)$ & $0.1807(1)$ & $0.0906(5)$ \\
AP & $0.0477(6)$ & $0.0461(6)$ & $0.0135(6)$ & $0.0729(6)$ & $0.0516(6)$ & $0.0100(6)$ \\
stage & $0.1173(4)$ & $0.1999(2)$ & $0.2018(3)$ & $0.0810(5)$ & $0.1122(4)$ & $0.1611(2)$ \\
tumor differentiation & $0.2170(2)$ & $0.2450(1)$ & $0.1931(4)$ & $0.1961(2)$ & $0.1798(2)$ & $0.0994(4)$ \\
\hline correlation ratio & 0.1733 & 0.1725 & 0.2238 & 0.1608 & 0.1423 & 0.1492 \\
\hline
\end{tabular}

( ) : order of significance as prognostic factor, PTS : patients 
Table 6 The relationship between cause of death and item

\begin{tabular}{|c|c|c|c|c|c|}
\hline \multirow{2}{*}{ item } & \multirow{2}{*}{ category } & \multicolumn{3}{|c|}{ cause of death } & \multirow{2}{*}{$\begin{array}{l}\text { statistical } \\
\text { evaluation }^{(a)}\end{array}$} \\
\hline & & prostate cancer & others & unknown & \\
\hline \multirow{4}{*}{ age } & 1 & 7 & 4 & 0 & \multirow{4}{*}{$* *$} \\
\hline & 2 & 27 & 10 & 5 & \\
\hline & 3 & 39 & 45 & 10 & \\
\hline & 4 & 10 & 21 & 5 & \\
\hline \multirow{3}{*}{$\begin{array}{l}\text { gait } \\
\text { disturbance }\end{array}$} & 1 & 60 & 62 & 12 & \multirow{3}{*}{ ns } \\
\hline & 2 & 16 & 11 & 6 & \\
\hline & 3 & 7 & 7 & 2 & \\
\hline \multirow{3}{*}{ ESR } & 1 & 37 & 35 & 9 & \multirow{3}{*}{ ns } \\
\hline & 2 & 27 & 36 & 5 & \\
\hline & 3 & 19 & 9 & 6 & \\
\hline \multirow{2}{*}{ AP } & 1 & 23 & 38 & 5 & \multirow{2}{*}{$* *$} \\
\hline & 2 & 60 & 42 & 15 & \\
\hline \multirow{4}{*}{ stage } & 1 & 0 & 10 & 1 & \multirow{4}{*}{$* *$} \\
\hline & 2 & 5 & 15 & 2 & \\
\hline & 3 & 17 & 18 & 3 & \\
\hline & 4 & 61 & 37 & 14 & \\
\hline \multirow{3}{*}{$\begin{array}{l}\text { tumor } \\
\text { differentiation }\end{array}$} & 1 & 6 & 13 & 1 & \multirow{3}{*}{ ns } \\
\hline & 2 & 29 & 31 & 10 & \\
\hline & 3 & 48 & 36 & 9 & \\
\hline
\end{tabular}

(a) : Statistical evaluation was performed between prostate cancer and others by chisquare test $\left({ }^{* *}: \mathrm{p} \leqq<0.01\right.$, ns : not significant).

は認められなかった(Table 6).ただし, ESRは category $50 \mathrm{~mm}$ 末満群と以上群に分け検討すると有意 の差 $(\mathrm{p} \leqq 0.05)$ が得られた。 また年齢は若い群に癌死 率が高かった。

死因別に多変量解析を行うに当たり，歩行障害にお ける車椅子・担送ならびに病期の A・B の各 2 群は症 例数が少な過ぎるので，それぞれ 1 群にまとめた。

数量化 I 類による前立腺癌死群 (Table 7) の解析結 果を偏相関係数の大きな順にみると, 病期・年齢・分 化度・ESR・AP・歩行障害であった。この時の病期が 示した偏相関係数は 0.4790 と全症例における結果 (Table 4)より高い値であった. category 間では AP のみが期待された生存日数と負の関連を示した。をた 全症例の項でみられた若年齢群の生存予後不良 (Table 4) は認められなかったが，59歳以下群 (category 1）と80歳以上群（category 4）の期待生存日数 はわずか473.7日しか異ならず若い年龄群の予後不良 傾向を示した。他因死群 (Table 8)における偏相関係 数の順位は歩行障害・年齢 - 病期 $\cdot \mathrm{ESR} \cdot$ 分化度・ AP であり, 歩行障害・年齢の偏相関係数子癌死群におけ るそれよりも上昇した。 category 間では年跲における 若年齢群の生存予後不良がここでは明らかに示され
Table 7 Multivariate analysis by quantification method I (in patients died of prostate cancer)

\begin{tabular}{l|r|r|r|r|l}
\hline \multirow{2}{*}{ item } & \multicolumn{4}{|c|}{ category } & $\begin{array}{c}\text { partial } \\
\text { coefficient }\end{array}$ \\
\cline { 2 - 5 } & \multicolumn{1}{c|}{1} & \multicolumn{1}{c|}{2} & \multicolumn{1}{c|}{3} & 4 & \\
\hline age & 229.5 & 47.6 & -11.5 & -244.2 & $0.2025(2)$ \\
$\begin{array}{l}\text { gait } \\
\text { disturbance }\end{array}$ & 59.1 & -154.3 & & & $0.1708(6)$ \\
ESR & 116.8 & -57.6 & -145.7 & & $0.1944(4)$ \\
AP & -169.5 & 65.0 & & & $0.1825(5)$ \\
stage & 581.4 & 536.6 & -197.2 & & $0.4790(1)$ \\
tumor \\
differentiation
\end{tabular}

constant term $=1738.1$ days correlation ratio $=0.6513$

( ) : order of significance as prognostic factor.

た。病期における category $1(\mathrm{~A}+\mathrm{B})$ においても期待 生存日数は負の相関がみられた。

数量化II 類を用いて, 前立腺癌死症例群 - と他因死 症例群を別々に検討した (Table 9，10). 前立腺癌死 群に扔いては，年齢・歩行障害は初年度のみ高い順位 を得たが以後下降した．ESR・APは中〜下の順位で あった。病期・分化度は初年度の及低い順位であった が以後は高い順位であった，死因に拘らず検討した時 より, 各 item もその重さについての順位, 偏相関係数 
も安定し, 相関比も上昇した. 他因死群についても数 量化II 類解析を用いて検討した。前立腺癌死群と対比 しながら結果を見ると，歩行障害の高順位は長期化し た. 年龄はこの群では $4 \sim 6$ 年目といら後半部分で高

Table 8 Multivariate analysis by quatification method I (in patients died of other causes)

\begin{tabular}{|c|c|c|c|c|c|}
\hline \multirow{2}{*}{ item } & \multicolumn{4}{|c|}{ category } & \multirow{2}{*}{$\begin{array}{c}\text { partial } \\
\text { coefficient }\end{array}$} \\
\hline & 1 & 2 & 3 & 4 & \\
\hline age & -455.9 & 324.7 & 69.1 & -212.5 & $0.2246(2)$ \\
\hline $\begin{array}{l}\text { gait } \\
\text { disturbance }\end{array}$ & 122.9 & -416.4 & & & $0.2585(1)$ \\
\hline ESR & 56.3 & 59.5 & -450.2 & & $0.1791(4)$ \\
\hline $\mathrm{AP}$ & 30.3 & -26.7 & & & $0.0303(6)$ \\
\hline stage & -279.7 & 234.4 & 81.2 & & $0.2027(3)$ \\
\hline $\begin{array}{l}\text { tumor } \\
\text { differentiation }\end{array}$ & 236.9 & 47.5 & -130.1 & & $0.1475(5)$ \\
\hline
\end{tabular}

constant term $=1191.8$ days, correlation ratio $=0.4043$

( ) : order of significance as prognostic factor.
い順位を占めていた，ESR・AP は両群同様な結果で あった。病期は $3 \sim 6$ 年度に高い順位を認めたが, そ の偏相関係数は前立腺癌死群における時よりも低かっ た. 分化度は観察 $1 \sim 2$ 年で高い順位と相関性を示し たが，以後急速に順位と偏相関係数は低下した。

IV. 病期 $\mathrm{ABC}$ と D における多変量解析

病期を $\mathrm{ABC}$ 群と $\mathrm{D}$ 群にわけ予後因子研究を行っ た。 歩行障害因子を 3 段階 category に分けると category 当たりの症例数が小さくなり過ぎるので, 自力歩 行可能群と歩行不能群の 2 段階 category で検討を加 えた. 検討された症例の item と category の関連は Table 11，12の如くであった。

病期 $\mathrm{ABC}$ 群の数量化 I 類解析結果に打ける各 category の期待生存日数をみると, ESR の20以下群・病 期 $\mathrm{A}+\mathrm{B}$ 群 ・分化度の中分化群が期待された生存日数 より短かった(Table 13)。偏相関係数は順位は年齢・ 歩行障害といった item が上位を占め, 分化度・病期が

Table 9 Multivariate analysis by quantification method II (in patients died of pca)

\begin{tabular}{l|c|c|c|c|c|c}
\hline observation year & 1 & 2 & 3 & 4 & 5 & 6 \\
\hline No. of alive PTS* & 59 & 39 & 21 & 11 & 8 & 5 \\
No. of dead PTS & 24 & 44 & 62 & 72 & 75 & 78 \\
\hline age & $0.3029(2)$ & $0.2532(3)$ & $0.1075(5)$ & $0.1185(5)$ & $0.0980(5)$ & $0.1581(2)$ \\
gait disturbance & $0.3580(1)$ & $0.0974(5)$ & $0.0917(6)$ & $0.0393(6)$ & $0.1319(2)$ & $0.0235(6)$ \\
ESR & $0.1374(4)$ & $0.1272(4)$ & $0.2262(4)$ & $0.2032(3)$ & $0.1142(4)$ & $0.1564(3)$ \\
AP & $0.1306(5)$ & $0.0194(6)$ & $0.2550(3)$ & $0.1802(4)$ & $0.0608(6)$ & $0.0825(4)$ \\
stage & $0.1414(3)$ & $0.2846(1)$ & $0.4991(1)$ & $0.3749(1)$ & $0.2906(1)$ & $0.3688(1)$ \\
tumor differention & $0.0758(6)$ & $0.2584(2)$ & $0.3209(2)$ & $0.2298(2)$ & $0.1291(3)$ & $0.0722(5)$ \\
\hline correlation & 0.3052 & 0.2754 & 0.4541 & 0.3189 & 0.1969 & 0.2428 \\
\hline
\end{tabular}

( ) : order of significance as prognostic factor

*PTS : patients

Table 10 Multivariate analysis by quantification method II (in patients died of other causes)

\begin{tabular}{l|c|c|c|c|c|c}
\hline observation year & 1 & 2 & 3 & 4 & 5 & 6 \\
\hline No. of alive PTS* & 60 & 46 & 28 & 18 & 11 & 6 \\
No. of dead PTS & 20 & 34 & 52 & 62 & 69 & 74 \\
\hline age & $0.2650(3)$ & $0.1198(6)$ & $0.1511(3)$ & $0.2076(3)$ & $0.2028(2)$ & $0.2545(1)$ \\
gait disturbance & $0.2978(2)$ & $0.2523(2)$ & $0.3472(1)$ & $0.2511(1)$ & $0.1133(4)$ & $0.1234(4)$ \\
ESR & $0.0868(5)$ & $0.1546(3)$ & $0.1216(5)$ & $0.1570(4)$ & $0.1799(3)$ & $0.1413(3)$ \\
AP & $0.0139(6)$ & $0.1260(4)$ & $0.0081(6)$ & $0.0889(6)$ & $0.0270(6)$ & $0.0189(6)$ \\
stage & $0.1532(4)$ & $0.1223(5)$ & $0.1700(2)$ & $0.2329(2)$ & $0.2476(1)$ & $0.2023(2)$ \\
tumor differentiation & $0.3972(1)$ & $0.2643(1)$ & $0.1378(4)$ & $0.1034(5)$ & $0.0797(5)$ & $0.0566(5)$ \\
\hline correlation ratio & 0.2833 & 0.1805 & 0.1679 & 0.1423 & 0.1230 & 0.1413 \\
\hline
\end{tabular}

( ) : order of significance as prognostic factor

*PTS : patients 
これに続いた. 基準生存日数は1,242.0日, 重相関係数 は0.3105であった。

病期 D 群に抢ける各 category の期待生存日数をみ

Table 11 Prognostic factors studied for stage A, $\mathrm{B}$ and $\mathrm{C}$

\begin{tabular}{|c|c|c|c|c|}
\hline \multirow{2}{*}{ item } & \multicolumn{4}{|c|}{ category } \\
\hline & 1 & 2 & 3 & 4 \\
\hline age & $\begin{array}{r}\leqq 59 \\
(7)\end{array}$ & $\begin{array}{c}60-69 \\
(36)\end{array}$ & $\begin{array}{c}70-79 \\
(87)\end{array}$ & $\underset{(31)}{\geqq 80}$ \\
\hline $\begin{array}{l}\text { gait } \\
\text { disturbance }\end{array}$ & $\begin{array}{c}\text { can walk } \\
(138)\end{array}$ & $\begin{array}{c}\text { cannot walk } \\
(23)\end{array}$ & & \\
\hline ESR & $\begin{array}{l}\leqq 20 \\
(90)\end{array}$ & $\begin{array}{c}21-50 \\
(54)\end{array}$ & $\begin{array}{l}>50 \\
(17)\end{array}$ & \\
\hline $\mathrm{AP}$ & $\begin{array}{c}\text { normal } \\
(102)\end{array}$ & $\begin{array}{c}\text { abnormal } \\
(59)\end{array}$ & & \\
\hline stage & $\underset{(27)}{A}$ & $\begin{array}{c}\mathrm{B} \\
(61)\end{array}$ & $\begin{array}{c}\mathrm{C} \\
(73)\end{array}$ & \\
\hline $\begin{array}{l}\text { tumor } \\
\text { differentiation }\end{array}$ & $\begin{array}{l}\text { well } \\
(42)\end{array}$ & $\underset{(67)}{\text { moderately }}$ & $\begin{array}{c}\text { poorly } \\
(52)\end{array}$ & \\
\hline
\end{tabular}

( ) : number of patients

Table 12 Prognostic factors studied for stage D

\begin{tabular}{|c|c|c|c|c|}
\hline \multirow{2}{*}{ item } & \multicolumn{4}{|c|}{ category } \\
\hline & 1 & 2 & 3 & 4 \\
\hline age & $\begin{array}{l}\leqq 59 \\
(12)\end{array}$ & $\begin{array}{r}60-69 \\
(49) \\
\end{array}$ & $\begin{array}{c}70-79 \\
(93) \\
\end{array}$ & $\begin{array}{l}\geqq 80 \\
(38)\end{array}$ \\
\hline $\begin{array}{l}\text { gait } \\
\text { disturbance }\end{array}$ & $\begin{array}{c}\text { can walk } \\
(144)\end{array}$ & $\begin{array}{c}\text { cannot walk } \\
(48)\end{array}$ & & \\
\hline ESR & $\begin{array}{l}\leqq 20 \\
(82)\end{array}$ & $\begin{array}{r}21-50 \\
(66)\end{array}$ & $\begin{array}{l}>50 \\
(44)\end{array}$ & \\
\hline $\mathrm{AP}$ & $\begin{array}{c}\text { normal } \\
(49)\end{array}$ & $\begin{array}{c}\text { abnormal } \\
(143)\end{array}$ & & \\
\hline $\begin{array}{l}\text { tumor } \\
\text { differentiation }\end{array}$ & $\begin{array}{r}\text { well } \\
(14)\end{array}$ & $\begin{array}{c}\text { moderately } \\
(86)\end{array}$ & $\begin{array}{c}\text { poorly } \\
(92)\end{array}$ & \\
\hline
\end{tabular}

( ) : number of patients
ると, 年齢の若年齢群・AP の正常群が期待生存日数よ り短かった (Table 14). 偏相関俰数の順位は ESR が 0.3168 と他より圧倒的に高い值を示した。分化度・年 齢といった itemがこれに続いた。基準生存日数は 1,352.8日，重相関係数は0.1742であった。

Table 13 Multivariate analysis by quantification method I (in patients with stage A, B or C)

\begin{tabular}{|c|c|c|c|c|c|}
\hline \multirow{2}{*}{ item } & \multicolumn{4}{|c|}{ category } & \multirow{2}{*}{$\begin{array}{c}\text { patical } \\
\text { coefficient }\end{array}$} \\
\hline & 1 & 2 & 3 & 4 & \\
\hline age & 940.7 & 397.7 & -126.8 & -123.9 & $0.3321(2)$ \\
\hline $\begin{array}{l}\text { gait } \\
\text { disturbance }\end{array}$ & 152.9 & -622.3 & & & $0.3969(1)$ \\
\hline ESR & -91.7 & 225.6 & -385.5 & & $0.2596(5)$ \\
\hline AP & 85.1 & -109.8 & & & $0.1149(6)$ \\
\hline stage & -403.3 & 98.2 & 173.6 & & $0.2660(4)$ \\
\hline $\begin{array}{l}\text { tumor } \\
\text { differentiation }\end{array}$ & 379.3 & -196.6 & -19.1 & & $0.2763(3)$ \\
\hline
\end{tabular}

constant term $=1242.0$ days, correlation ratio $=0.3105$ ( ) : order of significance as prognostic factor

Table 14 Multivariate analysis by quantification method I (in patients with stage D)

\begin{tabular}{|c|c|c|c|c|c|}
\hline \multirow{2}{*}{ item } & \multicolumn{4}{|c|}{ category } & \multirow{2}{*}{$\begin{array}{c}\text { partical } \\
\text { coefficient }\end{array}$} \\
\hline & 1 & 2 & 3 & 4 & \\
\hline age & -25.1 & -6.7 & 114.7 & -203.0 & $0.1914(3)$ \\
\hline $\begin{array}{l}\text { gait } \\
\text { disturbance }\end{array}$ & 65.3 & -143.7 & & & $0.1371(4)$ \\
\hline AP & -146.6 & 44.3 & & & $0.1149(5)$ \\
\hline ESR & 278.3 & 103.3 & -296.6 & & $0.3168(1)$ \\
\hline $\begin{array}{l}\text { tumor } \\
\text { differentiation }\end{array}$ & 334.4 & 128.1 & 116.0 & & $0.1954(2)$ \\
\hline
\end{tabular}

Table 15 Multivariate analysis by quantification method II (in patients with stage A, B or C)

\begin{tabular}{l|c|c|c|c|c|c}
\hline $\begin{array}{l}\text { No. of alive PTS* } \\
\text { No. of dead PTS }\end{array}$ & $\begin{array}{c}136 \\
12\end{array}$ & $\begin{array}{c}114 \\
23\end{array}$ & $\begin{array}{c}83 \\
38\end{array}$ & $\begin{array}{c}50 \\
55\end{array}$ & $\begin{array}{c}38 \\
62\end{array}$ & $\begin{array}{c}24 \\
65\end{array}$ \\
\hline observation year & 1 & 2 & 3 & 4 & 5 & 6 \\
\hline age & $0.0079(6)$ & $0.1588(6)$ & $0.1909(2)$ & $0.3762(3)$ & $0.3653(1)$ & $0.3956(1)$ \\
gait disturbance & $0.3416(1)$ & $0.3303(2)$ & $0.3974(1)$ & $0.2962(1)$ & $0.2280(2)$ & $0.2139(2)$ \\
ESR & $0.0417(5)$ & $0.0877(3)$ & $0.0863(6)$ & $0.0549(4)$ & $0.0409(6)$ & $0.0506(6)$ \\
AP & $0.0636(4)$ & $0.0639(4)$ & $0.1570(4)$ & $0.2617(6)$ & $0.2207(3)$ & $0.1574(3)$ \\
stage & $0.1029(3)$ & $0.1649(5)$ & $0.1279(5)$ & $0.0924(2)$ & $0.1218(5)$ & $0.1259(4)$ \\
tumor differentiation & $0.2120(2)$ & $0.1221(1)$ & $0.1759(3)$ & $0.1707(5)$ & $0.1305(4)$ & $0.1265(5)$ \\
\hline correlation ratio & 0.1846 & 0.1653 & 0.2214 & 0.2545 & 0.2279 & 0.2201 \\
\hline
\end{tabular}

( ) : order of significance as prognostic factor

*PTS : patients 
Table 16 Multivariate analysis by quantification method II (in patients with stage D)

\begin{tabular}{l|c|c|c|c|c|c}
\hline $\begin{array}{l}\text { No. of alive PTS* } \\
\text { No. of dead PTS }\end{array}$ & $\begin{array}{c}147 \\
35\end{array}$ & $\begin{array}{c}99 \\
63\end{array}$ & $\begin{array}{c}60 \\
89\end{array}$ & $\begin{array}{c}42 \\
95\end{array}$ & $\begin{array}{c}28 \\
98\end{array}$ & $\begin{array}{c}15 \\
106\end{array}$ \\
\hline observation year & 1 & 2 & 3 & 4 & 5 & 6 \\
\hline age & $0.1300(3)$ & $0.1540(3)$ & $0.1532(4)$ & $0.2144(3)$ & $0.1683(3)$ & $0.2097(3)$ \\
gait disturbance & $0.2642(1)$ & $0.1444(4)$ & $0.1935(3)$ & $0.1084(5)$ & $0.0715(5)$ & $0.1715(4)$ \\
ESR & $0.0749(4)$ & $0.1579(2)$ & $0.3160(1)$ & $0.3568(1)$ & $0.3198(1)$ & $0.2304(2)$ \\
AP & $0.0367(5)$ & $0.1173(5)$ & $0.0980(5)$ & $0.1160(4)$ & $0.1360(4)$ & $0.1582(5)$ \\
tumor differentiation & $0.2018(2)$ & $0.2784(1)$ & $0.2395(2)$ & $0.2382(2)$ & $0.2227(2)$ & $0.2455(1)$ \\
\hline correlation ratio & 0.1371 & 0.1607 & 0.2139 & 0.2284 & 0.1818 & 0.1706 \\
\hline ( ): order of siginificance as prognostic factor \\
*PTS : patients
\end{tabular}

病期 ABC 群の数量化II 類解析に打いて偏相関係数 の各 item の変動をみると (Table 15), 歩行障害は常 時高値を，年齢は前期 $1 \sim 3$ 年に低值であったが後期 $5 \sim 6$ 年では高い值を示した. 病期 D において同様な 検討を行った(Table 16). 歩行障害は初年度の夕高い 偏相関係数值を，年齢は後期に高い傾向を示した。 ESR は 3 年目より高い値を, 分化度は常時 1 ないし 2 位の順位を示した。

\section{考 察}

全例を対象とした時，年齢と歩行障害・ESR と歩行 障害・病期と分化度・病期と AP・分化度と AP の間に 相関性 (Table 2) が得られた事はほぼ我々の臨床認識 に近いものとして納得がいった。しかし年龄と AP の 間に相関性が認められたことは予想外であった。年齢 と病期との間には相関性は認められず, 高龄者に特に AP 值が高い症例がいたわけでもなく AP 産生能が高 まっているとは思えなかった(結果割愛)。また高龄者 に打ける肝・腎あるいは他の AP 排泄機構が低下する ことによって生じているとも考えたが確証はない。

今回の対象症例群では AP を正常と異常に分け検討 したが，生存率の有意の差を認めることが出来なかっ た。また, categoryを 2 倍以下と以上に分けても同様 であった。今回の対象症例の母体となった 1,087 例中, AP が測定された712例について正常值の 2 倍以下と 以上で検討すると生存率に有意の差が見出された（結 果割愛).この様に AP の生存因子としての評価はかな り微妙なものであり, 検討症例数によってはこの様な 結果になるものとも思われる。しかし，AP の癌死因子 としての有用性は認められた。癌死群のみの検討 (Table 7) では期待される生存日数は“正常”は“異 常”に比べ短かった。これは病期 D症例のみの解析 (Table 14)に扔いても認められた。単純に解釈するな らば，癌死する正常 AP 值を示す（あるいは病期 D の
正常 AP 值を示す）症例は癌死する異常 AP 值（ある いは病期 D の異常 AP 值を示す) 症例より予後不良と なるが，これは我々の一般的経験とは合わない，本研 究では 3 種類の測定法によって得られた AP 值を正常 值上限との比にて評価をしたが，それらの前立腺癌に 対する感度 (sensitivity) は異なっている ${ }^{10)}$ とれてい るので，同一測定に限定した解析が好ましい様に思わ れる.しかし, 測定法別検討では 1 群当たりの症例が 少なくなり, RIA 測定法群では観察期間が短いといっ た問題があったので本研究は測定法を考慮にいれずに 行われた，AP 測定法あるいは正常値/異常値とした category 化ならびに治療への反応性を含め再検討さ れるべき問題である。

全症例を対象とした時, 数量化 I 類では全身状態を 表すものが予後因子として重要度が高かった事はこの 疾患の特性を物語っている。死因解析でも本疾患の約 半数は前立腺癌以外の疾患で死亡している事も上記と 同じ理由によると考えて良いであろう，そこで，より 純化した前立腺癌予後因子の研究の為, さらに症例群 を死因あるいは病期別に分け検討した。癌死症例にお ける検討では年齢・歩行障害といった全身状態と密接 に関連すると思われる itemに代り, 病期あるいは分 化度といった癌一般の予後因子研究で重要とされてい る item ${ }^{3}$ が予後因子として重要度を増した。また病期 $\mathrm{D}$ に前立腺癌死が多い事より病期を $\mathrm{ABC}$ と D に分け 検討したが，前者では全身状態関連因子が，後者では ESR と分化度が予後因子としての重さを評価された。

ESR は唃血・血中タンパク濃度・感染といった全身 状態と密接に関連している事が知られているので11), ESR は全身状態を表すitem として我々は考えてい た。しかし，多変量解析結果は, ESR が病期 D 前立前 立腺癌の重要な予後因子であり, 観察年数が 3 年以上 となった時より重要度が発揮される因子と考えられ 
る.こういった結果は我々がこれら取組もらとしてい る時間経過と予後因子価值変化の相関性すなわち time dependent prognostic factorの必要性を示唆し ている12).

本研究の年齢因子解析結果では全症例における検討 (Table 4)・癌死の解析 (Table 6) ならびに病期別検 討 (Table 14) のいずれも年齢因子に抢ける “若年齢” は負の生存因子であり, 癌死と有意の相関性を示すむ のであった。この結論は若年齢者における癌は高齡者 のそれよりも，より生命に対して危険度の高いもので あるといら考方方 ${ }^{1314)}$ によっても支持される。しかし， 死因別検討 (Table 7，8）では逆に癌死症例の若年齢 群は期待生存日数が長く, 非癌死群が短いといら一見 矛盾する結果が得られたが, 若年群と高龃群の期待生 存率の差をを思䒚ば若年群の予後は不良と考兄られ る.

今回の対象母体となった 1,087 例においても, 病期 $\mathrm{A}$ 症例の生存率は病期 $\mathrm{B}$ と C の間に在り,この生存率 は癌死の影響をまったく受けていない(結果割愛)、今 回の全症例における検討 (Table 4) において, 病期 A の期待される生存日数は-276.9日 と病期 D の-69.4 日より短かった。死因別検討 (Table 8, ここでは病期 $\mathrm{A}+\mathrm{B}$ として検討) 病期別検討 (Table 13) に扔いて も同様な結果が得られた。これに対して適切な説明が 出来ない.

本研究は治療法に関する因子はまったく考慮にいれ ずに行われた。しかし，この中には早期癌における前 立腺全摘や内分泌療法に打けるLHRH agonist と いった予後に影響を与える可能性が含まれている問題 も多く今後の検討課題となった。

本研究における対象症例数が353であった事はいま だ我々の施行しょらとしている研究目標に充分に耐兄 られる数ではない。幸い, 我々のグループには毎年約 130例以上の新鮮前立腺癌が登録されてくる体制が 整っているので15)，近い将来これらを対象にCox 比例 Hazard 検定による解析を行う予定である.

$$
\text { 文 献 }
$$

1) Sylvester, R.J., Suciu, S. and Yamanaka, H.: Prognostic factors for randomization and stratification and endopoints for the evaluation of trials. in EORTC Genitourinary Group Monograph 5: Progress and Controversies in Oncological Uroligy 2, p. 275, Alan, R., Liss, Inc., Paris, 1988.

2) Emrich, L.J., Piore, R.L., Murphy, G.P., Brady, M.F. and the Investigtors National Prostatic
Cancer Project: Prognostic factors in patients with advanced stge prostate cancer. Cancer Research, 45, 5173-5179, 1985.

3) Molinari, R. and Bonadonna, G.: General Prognostic Factors. Handbook of Medical Oncology. 3rd ed., p. 45-52, Masson, Milano, 1988.

4) Pilepich, M.V., Krall, J.M., Sause, W.T., Johnson, R.J., Russ, H.H., Hanks, G.E., Perez, C.A., Zinninger, M. and Martz, K.L.: Prognostic factors in carcinoma of the prostate-analysis of RTOG study 75-06. Int, Radiation Oncology Biol. Phys., 13, 339-349, 1987.

5) Carlson, N.L.T., Christesen, I.B.J., Schroeder, H., Bro, V., Erichsen, G., Hamborg-Pedersen, B., Jensen, K.B. and Nielsen, O.H. : Prognostic factors in neuroblastomas treated in Denmark from 1943 to 1980. Cancer, 58, 2726-2735, 1986.

6) Henry, K. Miller, J., Loening, S. and Fallon, B. : Comparison of transurethral resectin to radical therapies for stage B bldder tumors. J. Urol., 140, 964-967, 1988.

7) WHO: Handbook for reporting results of cancer treatment. WHO offset publication, No. 48, Geneva, 1979.

8) 前立腺癌取扱い規約. 第 1 版, 日本泌尿器科学会日本病理学会編. 金原出版, 東京, 1985.

9）古川俊之, 田中 博: 重回㷌分析. 数量化 I, II 類. 多変量解析プログラムパッケイージ入門. 第 1 版, p. 17-39, p. 128-150, 医学書院, 東京, 1983.

10) Bruce, A.W. and Choe, B.K.: Tumor Markers in Prostatic Disease. in Adenocarcinoma of prostate. p. $47-62$, Springer-Verlag, London, 1987.

11）三輪史朗：血液検査. 臨床検查提要, 29 版, p. 225 -319, 金原出版, 東京, 1983.

12) Suciu, S., Sylvester, R.J. and Yamanaka, H.: Time dependent prognostic factors in advanced prostatic cancer. (in press)

13) Wilson, D.W., Harper, H.M., Jensen, H.M., Ikeda, R.M., Richards, G., Peeling, W.B., Pierrepoint, C.G., and Griffiths, K.: A prognostic index for the clinical management of patients with advanced prostatic cancer: A british prostate study group investigation. Prostate, 7 , 131-141, 1985.

14) Catalona, W.J. and Scoatt, W.W.: Carcinoma of the Prostate. Campbell's Urology, Vol. 2, 4th ed., p. 1085-1124, Sauders Co., Philadelphia, 1979.

15）中田誠司, 松尾康滋, 清水信明, 川島清隆, 今井強 一, 山中英寿, 黑沢 功, 喜連秀夫, 三木正也, 清 水嘉門：群馬県における前立腺癌患者の臨床統計 的観察. 北関東医学, 38, 143-147, 1988.

(1990年 5 月 2 日受理) 